\title{
Meningkatkan Hasil Belajar Siswa pada Materi Persamaan Kuadrat Melalui Penerapan Model Problem Based Learning
}

\author{
Improving Student Learning Outcomes in Quadratic Equation through Problem Based \\ Learning Model
}

\author{
K. Savitri*, M. Rizal, Linawati \\ Prodi Pendidikan Matematika FKIP UNTAD, Palu, Indonesia \\ *e-mail: vitriadek08@gmail.com
}

\begin{tabular}{l}
\hline Article Info \\
\hline Article History: \\
Received: 30 April 2021 \\
Accepted: 24 Mei 2021 \\
Published: 31 Mei 2021 \\
Keywords: \\
Model Problem Based \\
Learning (PBL) \\
Student Learning \\
Quadratic Equation \\
\end{tabular}

\section{PENDAHULUAN}

Pendidikan matematika merupakan salah satu sarana yang sangat penting dalam upaya membina dan membentuk sumber daya manusia yang berkualitas. Mengingat nilai penting matematika bagi masyarakat, maka tidak mengherankan jika matematika merupakan salah satu mata pelajaran pokok yang wajib diberikan di sekolah, mulai dari tingkat Sekolah Dasar (SD) sampai Perguruan Tinggi sebagai sarana berpikir untuk menumbuhkembangkan pola berpikir kritis, logis, sistematis, objektif, dan rasional.

Telah banyak usaha pemerintah untuk meningkatkan mutu pendidikan di Indonesia diantaranya adanya penyesuaian kurikulum, namum belum memperoleh hasil yang maksimal. Hal ini dapat dilihat dari hasil-hasil ujian/evaluasi yang tidak merata antara wilayah bahkan perbedaan sangat tajam, sehingga mengindikasikan masih banyak kesalahan-kesalahan yang dihadapi siswa terutama bidang matematika.

Matematika merupakan suatu mata pelajaran yang sangat penting karena matematika senantiasa mendukung mata pelajaran yang lain seperti mata pelajaran fisika, geografi, ekonomi dan mata pelajaran lainnya. Pemahaman konsep dari mata pelajaran lain yang memerlukan dukungan dari konsep matematika menjadikan matematika merupakan proses yang berkesinambungan untuk memperoleh konsep ide dan pengetahuan baru yang berdasarkan pengalamanpengalaman sebelumnya karena setiap siswa diharapkan benar-benar menguasai konsep yang diberikan karena konsep tersebut akan digunakan untuk mempelajari materi berikutnya.

Berdasarkan hasil dialog dengan salah satu guru di SMA Negeri 1 Torue, tentang refleksi pembelajaran yang telah diberikan dalam kelas diperoleh informasi bahwa guru mengalami kesulitan dalam membelajarkan materi persamaan kuadrat. Hal ini dapat dilihat dari hasil ulangan harian persamaan kuadrat kelas X IPA4 tahun ajaran 2016/2017. Dari 32 siswa, hanya 14 orang yang mendapat nilai 75-90, dan 18 orang mendapat nilai kurang dari 75. Jika dikaitkan dengan kriteria ketuntasan minimal di SMA Negeri 1 Torue yakni 75, maka siswa yang dikategorikan tuntas mencapai $43,75 \%$ dari jumlah keseluruhan siswa kelas $X$ IPA4. Menurut penuturan guru tersebut, siswa kurang memahami cara menyelesaikan persamaan kuadrat ax $2+b x$ $+\mathrm{c}=0 ; \mathrm{a} \neq 0$, khususnya $\mathrm{a} \neq 1$ dengan cara memfaktorkan, 
melengkapkan kuadrat sempurna dan dengan rumus persamaan kuadrat.

Informasi lain juga diperoleh bahwa partisipasi siswa di dalam pembelajaran masih sangat rendah. Pada saat pembelajaran siswa tidak bertanya pada guru maupun siswa yang lain meskipun sebenarnya mereka belum mengerti tentang materi yang disampaikan. Saat guru menanyakan bagian mana yang belum dimengerti seringkali siswa hanya diam, dan setelah guru memberikan soal latihan maka terlihat bahwa ada beberapa siswa yang sebenarnya belum memahami materi yang diajarkan. Dalam mengerjakan soal latihan, sebagian tidak menjawab bahkan ada siswa yang sangat tergantung kepada siswa yang berkemampuan tinggi. Hal ini mengakibatkan hasil pembelajaran masih jauh dari harapan.

Mengatasi hal itu berbagai cara yang telah dilakukan guru antara lain, menggunakan pembelajaran langsung dan tanya jawab, akan tetapi guru belum dapat meningkatkan hasil belajar siswa sehingga guru tersebut menggunakan pembelajaran kooperatif. Hal ini bertujuan agar siswa yang jarang mengajukan pertanyaan atau menjawab pertanyaan dari guru tersebut mereka dapat bertanya kepada temannya yang lebih tahu sehingga mereka dapat aktif dalam pembelajaran. Tetapi pada saat belajar kelompok hanya siswa yang berkemampuan tinggi mengerjakan tugas sendirisendiri dan siswa lainnya hanya bermain sehingga tidak adanya saling membantu atau saling mengajarkan dalam kelompok. Pada saat guru menyuruh siswa untuk mempresentasikan hasil pekerjaannya siswa yang maju ke depan hanya siswa yang berkemampuan tinggi saja.

Berdasarkan uraian di atas peneliti mencoba berkolaborasi dengan guru untuk mengatasi masalah di kelas tersebut. Pada kolaborasi tersebut peneliti mencoba menerapkan suatu model pembelajaran Problem Based Learning (PBL) yang dapat merangsang siswa berpartisipasi aktif dalam pembelajaran sehingga dapat memperoleh hasil belajar yang optimal. Alasan peneliti memilih model pembelajaran PBL karena pada fase pertama yaitu orientasi siswa pada masalah, siswa dapat berpatisipasi aktif dalam pembelajaran dengan memperhatikan penjelasan guru dan mengidentifikasi masalah yang disajikan oleh guru serta siswa mencari cara pemecahan masalah yang diberikan guru. Pada fase kedua yaitu mengorganisasikan siswa untuk belajar, siswa akan membentuk sebuah kelompok yang terdiri dari 6 orang dengan memperhatikan arahan yang diberikan oleh guru. Pada fase ketiga yaitu membantu investigasi mandiri dan kelompok, siswa bekerjasama dengan teman kelompoknya untuk mengerjakan tugas yang diberikan oleh guru dan berdiskusi dengan teman kelompoknya. Pada fase keempat yaitu mengembangkan dan menyajikan hasil karya, setiap kelompok akan mempersiapkan dirinya untuk menyampaikan hasil kerja kelompoknya. Pada fase kelima yaitu menganalisis dan mengevaluasi proses pemecahan masalah, siswa dapat bertanya kepada guru jika ada hal-hal yang belum dipahami.

Rumusan masalah dalam penelitian ini yaitu bagaimana meningkatkan hasil belajar siswa kelas X IPA4 SMA Negeri 1 Torue pada materi persamaan kuadrat melalui penerapan model pembelajaran PBL? Tujuan penelitian ini untuk memperoleh deskripsi tentang penerapan model pembelajran PBL untuk meningkatkan hasil belajar siswa kelas X IPA4 SMA Negeri 1 Torue pada materi persamaan kuadrat.

\section{METODE PENELITIAN}

Jenis penelitian ini ialah penelitian tindakan kelas yang dilaksanakan dalam dua siklus. Setiap siklus dilaksanakan berdasarkan perubahan yang dicapai. Desain penelitian ini mengacu pada diagram yang dikembangkan oleh Kemmis dan Mc.Taggart [1]. Tiap siklus dilakukan dalam beberapa tahap, yaitu (1) tahap pra tindakan atau perencanaan, (2) pelaksanaan tindakan dan observasi, dan (3) refleksi. Tahap pelaksanaan tindakan dan observasi dilakukan pada satu waktu yang sama.

Subjek penelitian ini adalah seluruh siswa kelas X IPA4 SMA Negeri 1 Torue yang berjumlah 36 orang, terdiri dari 10 laki-laki dan 26 perempuan yang terdaftar pada tahun ajaran 2018/2019. Kemudian, dari subjek penelitian dipilih 3 siswa sebagai informan yaitu: satu siswa berkemampuan tinggi berinisial NP, satu siswa berkemampuan sedang berinisial $\mathrm{MG}$ dan satu siswa berkemampuan rendah berinisial SM. Teknik analisis data terdiri dari kondensasi data, menyajikan data dan penarikan kesimpulan.

Kegiatan peneliti dan siswa dalam proses pembelajaran dengan menggunakan model pembelajaran PBL dapat dinyatakan berhasil apabila total skor yang diperoleh berada dalam kategori baik atau sangat baik. Tindakan dikatakan berhasil jika persentase ketuntasan belajar minimum $75 \%$, dengan ketuntasan individu minimal 75(berdasarkan KKM yang ditetapkan di SMA Negeri 1 Torue).

\section{HASIL DAN PEMBAHASAN}

\section{Hasil}

Hasil penelitian ini terdiri atas dua bagian, yaitu hasil pratindakan dan hasil pelaksanaan tindakan. Pada pelaksanaan pratindakan, peneliti malakukan tes awal kepada siswa kelas $\mathrm{X} \mathrm{IPA}_{4}$ yang berjumlah 36 orang siswa. Hasil tes awal menunjukkan bahwa sebagian siswa belum mampu menyelesaikan soal dengan benar. Umumnya sebagian besar siswa belum dapat menentukan hasil dari operasi hitung penjumlahan, pengurangan dan perkalian dua buah bilangan, operasi hitung aljabar, bentuk pangkat dan bentuk akar. Hal ini terlihat dengan masih adanya sebagian siswa yang menjawab soal dengan keliru, sehingga memberikan gambaran bahwa hasil belajar siswa terhadap materi prasyarat masih sangat rendah. Adapun tujuan dari tes awal yakni untuk melihat kemampuan prasyarat siswa dan untuk membentuk kelompok- kelompok belajar yang heterogen.

Penelitian ini terdiri atas dua siklus. Setiap siklus dilaksanakan dalam dua kali pertemuan. Kegiatan pada pertemuan pertama siklus I yaitu melaksanakan pembelajaran dengan materi menemukan konsep persamaan kuadrat dan penerapannya dalam menyelesaikan masalah pada kehidupan sehari-hari. Kegiatan pada pertemuan kedua yaitu memberikan tes akhir tindakan siklus I. Pertemuan pertama pada siklus II yaitu melaksanakan pembelajaran dengan 
materi menentukan akar-akar persamaan kuadrat dan penerapannya dalam menyelesaikan masalah pada kehidupan sehari-hari. Pertemuan kedua yaitu memberikan tes akhir tindakan siklus II. Pertemuan pertama pada siklus I dan siklus II dilaksanakan dalam tiga tahap, yaitu 1) kegiatan pendahuluan, 2) kegiatan inti, dan 3) kegiatan penutup. Pelaksananaan tindakan setiap siklus mengikuti fase- fase model pembelajaran PBL, yaitu 1) orientasi siswa pada masalah, 2) mengorganisasikan siswa untuk belajar, 3) membantu penyelidikan individual maupun kelompok, 4) mengembangkan dan menyajikan hasil karya, dan 5) menganalisis dan mengevaluasi proses pemecahan masalah.

Kegiatan pendahuluan dimulai dengan peneliti membuka pembelajaran dengan mengucapkan salam, mengajak siswa untuk berdoa bersama, mengecek kehadiran siswa dan menyiapkan siswa untuk belajar. Kegiatan tersebut dapat menarik perhatian siswa di awal pembelajaran. Hal ini dapat dilihat saat siswa memberikan respon balik terhadap kegiatan yang dilakukan oleh peneliti. Pertemuan pertama dan kedua pada siklus I dan siklus II dihadiri oleh seluruh siswa kelas $\mathrm{X}$ IPA $^{4}$ yakni 36 orang siswa. Kemudian peneliti menyampaikan tujuan pembelajaran yang hendak dicapai. Tujuan pembelajaran pada siklus I yaitu siswa dapat memahami konsep persamaan kuadrat dan siswa dapat menyelesaikan soal yang berkaitan dengan persamaan kuadrat, sedangkan tujuan pembelajaran pada siklus II yaitu siswa dapat menentukan akar-akar persamaan kuadrat dengan cara melengkapkan kuadrat sempurna dan rumus ABC dan siswa dapat menyelesaikan soal yang berkaitan dengan persamaan kuadrat dengan tepat. Pada kegiatan ini siswa telah mengetahui tujuan pembelajaran yang hendak dicapai sehingga siswa terarah dalam mengikuti pembelajaran.

Peneliti memotivasi siswa-siswa dengan menyampaikan manfaat mempelajari materi persamaan kuadrat dalam kehidupan sehari-hari. Setelah siswa mengetahui manfaat mempelajari materi persamaan kuadrat, siswa termotivasi mengikuti pembelajaran. Kemudian, peneliti melakukan apersepsi dengan mengingatkan kembali kepada siswa mengenai materi prasyarat. Materi prasyarat pada siklus I ialah materi operasi bilangan, sedangkan materi prasyarat pada siklus II ialah materi yang diajarkan pada siklus I yaitu konsep persamaan kuadrat. Siswa yang menguasai materi prasyarat tidak mengalami kesulitan dalam mempelajari materi persamaan kuadrat.

Kegiatan inti diawali dengan melaksanakan fase 1 yaitu orientasi siswa pada masalah. Pada siklus I, peneliti mengorientasikan permasalahan kepada siswa dengan mempresentasikan materi dan memberikan contoh kepada siswa mengenai materi persamaan kuadrat dengan metode tanya jawab. Pada siklus II, peneliti memberikan permasalahan kepada siswa dengan mempresentasikan materi dan memberikan contoh soal mengenai materi akarakar persamaan kuadrat dean metode tanya jawab. Hasil yang didapatkan pada fase ini yaitu pada siklus I sebagian besar siswa memperhatikan penyampaian peneliti dan aktif mencari tahu konsep persamaan kuadrat, pada siklus II siswa memperhatikan penjelasan peneliti dengan baik berkaitan permasalahan yang diberikan.

Aktivitas pada fase 2 yaitu mengorganisasikan siswa untuk belajar. Pada siklus I dan siklus II, peneliti membagi siswa dalam kelompok belajar heterogen, yaitu sebanyak 6 kelompok belajar yang telah ditentukan sebelumnya dan membagikan LKPD pada masing-masing kelompok. Hasil yang didapatkan pada fase ini di siklus I adalah masih ada siswa yang menunjukkan ketidaksetujuannya kepada peneliti tentang anggota kelompoknya yang telah ditentukan. Hal ini dikarenakan siswa tersebut merasa kesulitan untuk berkomunikasi dan berdiskusi secara baik dengan salah satu anggota kelompoknya. Hasil yang didapatkan pada fase ini di siklus II adalah semua siswa membentuk kelompok sesuai dengan anggota kelompok pada siklus I.

Aktivitas pada fase 3 yaitu membantu penyelidikan individual maupun kelompok. Peneliti meminta siswa untuk melakukan penyelidikan kelompok untuk mengerjakan LKPD lalu mendiskusikan hasil jawaban LKPD dalam kelompok belajar masing-masing. Saat siswa mengerjakan LKPD, peneliti berkeliling memantau dan mengontrol jalannya diskusi kelompok juga memberikan bimbingan atau petunjuk terbatas pada siswa yang berkaitan dengan melakukan penyelidikan kelompok mengenai konsep persamaan kuadrat. Pada tahap ini, peneliti memberikan kesempatan kepada siswa untuk bertanya tentang hal-hal yang kurang dipahami. Hasil yang didapatkan pada fase ini adalah siswa mampu untuk mengungkapkan ide-ide mereka dalam menjawab masalah yang ada dalam LKPD melalui diskusi kelompok. Namun, pada fase ini di siklus I peneliti masih terlalu banyak memberikan bantuan sehingga masih perlu diperbaiki sedangkan pada siklus II, siswa sudah mampu menentukan akar-akar persamaan kuadrat dengan bantuan seperlunya dari peneliti jika siswa mengalami kesulitan.

Aktivitas pada fase 4 yaitu mengembangkan dan menyajikan hasil karya. Peneliti menunjuk siswa secara acak untuk mempresentasikan hasil pekerjaan kelompoknya. Hasil yang didapatkan pada siklus I dan siklus II adalah siswa sudah mampu mempresentasikan hasil pekerjaan kelompoknya dengan penguasaan topik dan proses pengerjaan yang cukup baik. Siswa dapat menjelaskan dengan baik konsep persamaan kuadrat dan akar-akar persamaan kuadrat.

Aktivitas pada fase 5 yaitu menganalisis dan mengevaluasi proses pemecahan masalah. Peneliti memberikan kesempatan kepada siswa untuk bertanya mengenai hasil presentasi yang dibawakan oleh temannya kemudian merefleksi kegiatan pembelajaran dengan cara tanya jawab. Hasil yang didapatkan pada siklus I siswa mampu menganalisis proses pemecahan masalah konsep persamaan kuadrat dan pada siklus II siswa mampu menanalisis pemecahan masalah akar-akar persamaan kuadrat. Hal ini terlihat saat siswa mampu menemukan kesalahan dan menjelaskan dengan baik jawaban yang benar saat tanya jawab.

Peneliti mengakhiri pembelajaran dengan mengajak siswa menyimpulkan secara umum materi yang telah 
dipelajari dan memberikan PR. Hasil yang didapatkan pada kegiatan ini adalah siswa sudah mampu dalam menyimpulkan konsep persamaan kuadrat pada siklus I dan sikus II siswa mampu menentukan akar-akar persamaan kuadrat. Hal ini terlihat saat sebagian besar siswa menanggapi seluruh pertanyaan peneliti tentang materi yang telah dipelajari dalam pembelajaran. Kemampuan siswa dalam membuat kesimpulan dengan baik ini dikarenakan siswa sudah dapat mengkonstruksi pengetahuan yang diperoleh pada saat bekerja dalam kelompok untuk menyelesaikan masalah. Peneliti menutup pembelajaran dengan mengajak siswa berdoa setelah belajar dan diiringi salam penutup dari semua siswa.
Selanjutnya pada pertemuan kedua dari setiap siklus, peneliti memberikan tes akhir tindakan kepada siswa. Tes akhir tindakan pada siklus I terdiri dari 2 nomor. Berikut satu diantara soal yang diberikan “ Seorang penjual komputer telah merakit komputer dengan biaya selama seminggu sebesar Rp 37.500.000,-. Hasil rakitannya selama seminggu dipasarkan dan berhasil terjual dengan sisa 3 unit. Jika hasil penjualan komputer Rp 36.0000.000,- dengan keuntungan tiap komputer Rp 500.000,-. Temukan persamaan kuadrat dari permasalahan tersebut dan tentukan akar-akar persamaan kuadrat tersebut dengan cara memfaktorkan". Satu diantara jawaban siswa pada soal tersebut adalah NP, sebagaimana ditunjukkan pada Gambar 1.
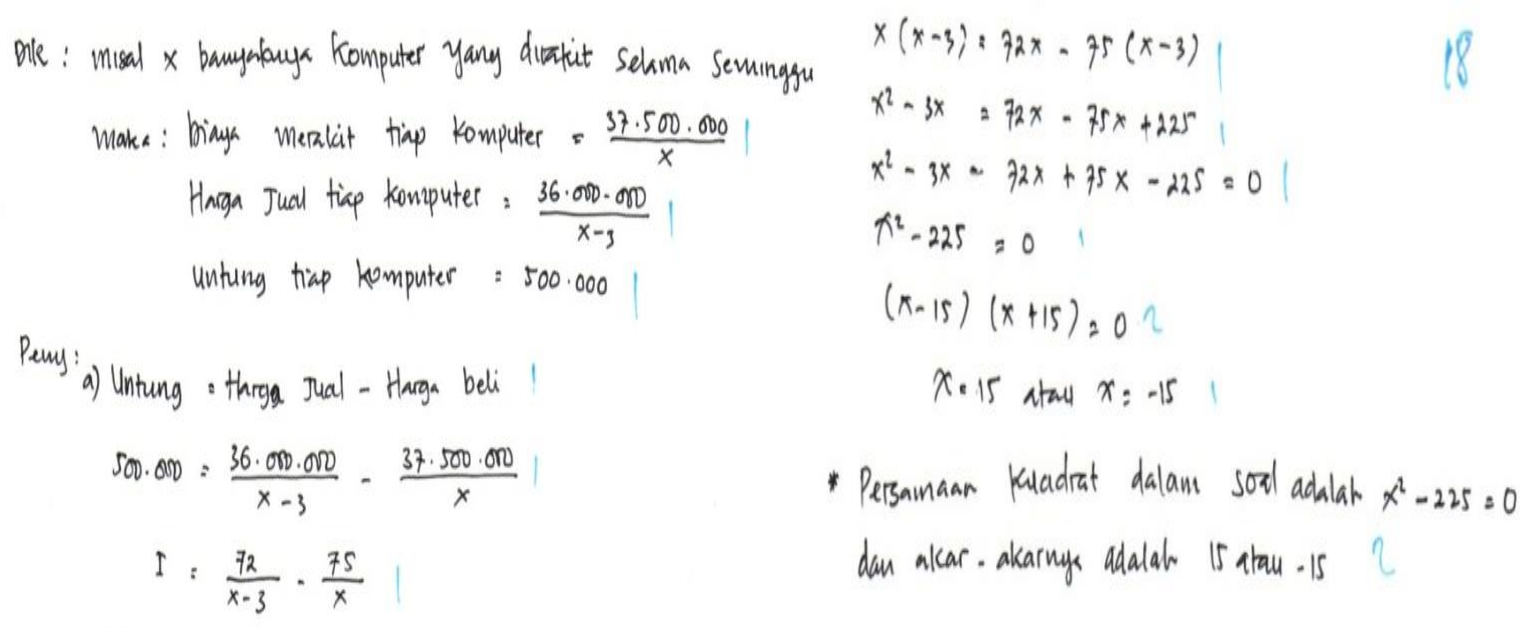

Gambar 1. Jawaban NP Soal Nomor 1 pada Tes Akhir Tindakan Siklus I

Berdasarkan Gambar 1 terlihat bahwa siswa NP telah menjawab soal sesuai dengan langkah-langkah yang telah diajarkan yaitu sudah dapat menemukan persamaan kuadrat dalam masalah, namun masih kurang lengkap. Karena NP tidak menuliskan apa yang ditanyakan pada soal.

NPS1 $11 \mathrm{P} \quad$ : Iya tuntas de, cuma masih kurang lengkap. Coba kamu perhatikan jawabanmu nomor 1 kamu tidak menuliskan apa yang ditanyakan pada soal.

NPS1 $12 \mathrm{~S} \quad$ : Iya kak, saya lupa sudah batulisnya kak, apa sudah cepat-cepat saya kerjakan. Nomor 2 ada juga salahnya kak?

NP S1 13 P : Tidak de, nomor 2 jawabanmu sudah benar dan lengkap. Nanti lain kali tuliskan apa yang ditanyakan ya, karna itu juga ada poinnya de.

NPS1 14 S : Baik kak, saya lupa sudah tulis karna mau cepat selesai kak.

NPS1 15 P : Ya sudah, terima kasih NP.

Berdasarkan hasil wawancara peneliti dengan siswa NP diperoleh informasi bahwa siswa NP sudah memahami langkah-langkah dalam menemukan persamaan kuadrat, hanya saja siswa NP tidak menuliskan apa yang ditanyakan dalam soal karena ingin cepat menyelesaikan soal.

Dari hasil tes akhir tindakan dan wawancara dengan siswa pada siklus I, diperoleh informasi bahwa sebagian siswa masih belum memahami langkah- langkah dalam menemukan persamaan kuadrat serta siswa masih kurang teliti dalam menentukan akar-akar persamaan kuadratnya. Hal tersebut dijadikan sebagai refleksi peneliti pada siklus I, sehingga pada siklus II peneliti berusaha lebih baik lagi dalam memberikan penjelasan kepada siswa.

Tes akhir tindakan siklus II terdiri dari 2 nomor, berikut satu diantara soal yang diberikan "berapakah ukuran-ukuran lebar yang mungkin dari kebun tersebut?". Satu diantara jawaban siswa pada soal tersebut adalah NP, sebagaimana ditunjukan pada Gambar 2. 


$$
\begin{aligned}
& \text { 2. Phe : } P=20+\ell \\
& L=(60 \cdot l)-375 \\
& \text { Dt: Lebar yang mungkin: ...? } \\
& \text { taluab: } h: P \cdot l \\
& 60 l-375=(20+l) \cdot l \\
& 60 l-375=20 l+e^{2} \\
& -l^{2}-20 l+60 l-3+5=0 \\
& l^{2}-90 l+375=0 l
\end{aligned}
$$

Gambar 2. Jawaban Siswa NP Soal Nomor 2 pada Tes Akhir Tindakan Siklus II

Berdasarkan Gambar 2 terlihat bahwa siswa NP telah menjawab soal dengan benar. Siswa NP dapat menemukan persamaan kuadrat dalam permasalahan dan dengan tepat dapat menentukan akar-akar persamaan kuadratnya sehingga dapat menyelesaikan soal dengan benar.

Guna memperoleh informasi lebih lanjut, peneliti melakukan wawancara dengan siswa NP sebagaimana kutipan wawancara berikut.

NP S2 09 P : Syukurlah, kakak juga sudah selesai memeriksa hasil ujianmu. Kamu dapat nilai sempurna.

NP S2 10 S : Iya kak. Syukurlah kak.

NP S2 $11 \mathrm{P} \quad$ : Sepertinya kamu sudah lebih teliti dalam menjawab soal. Pertahankan, dan jangan lupa belajar lagi biar ujian berikutnya bisa dapat nilai sempurna lagi. NP S2 12 S : Iya kak.

Berdasarkan hasil wawancara peneliti dengan siswa NP diperoleh informasi bahwa siswa NP sudah memahami langkah-langkah menemukan persamaan kuadrat dan menentukan akar-akarnya serta siswa NP juga semakin teliti dalam mengerjakan soal sehingga tidak mengulangi kembali kesalahannya pada siklus 1 .

Dari hasil tes akhir tindakan dan wawancara dengan siswa diperoleh informasi bahwa siswa sudah mengetahui dan memahami persamaan kuadrat serta cara menentukan akar-akarnya.

\section{Pembahasan}

Sebelum melaksanakan tindakan, peneliti melaksanakan tahap pra penelitian yaitu peneliti memberikan tes awal untuk mengetahui pengetahuan prasyarat siswa mengenai persamaan kuadrat. Pelaksanaan tes awal bertujuan untuk mengetahui kemampuan awal siswa yang didukung oleh pendapat Sutrisno [2] yang menyatakan bahwa pelaksanaan tes sebelum perlakuan dilakukan untuk mengetahui kemampuan awal siswa.

Pemberian tes awal sekaligus digunakan untuk pembentukan kelompok belajar yang heterogen dan penentuan informan berdasarkan kemampuan matematikanya. Berdasarkan analisis tes awal diperoleh informasi bahwa perolehan skor siswa rendah dengan ketuntasan belajar klasikal sebesar 30,5\%. Peneliti menyadari bahwa materi prasyarat merupakan modal awal siswa untuk memahami materi selanjutnya, sehingga sebelum pelaksanaaan tindakan dengan menerapkan model PBL peneliti kembali membahas soal dan hasil pekerjaan siswa pada tes awal dengan tujuan agar kesulitan yang dialami siswa pada tes awal tidak lagi menjadi hambatan pada pelaksanaan tindakan.

Kegiatan awal (pendahuluan) yang dilakukan peneliti adalah dengan mengawali pembelajaran dengan mengucapkan salam, mengajak siswa berdoa bersama, mengecek kehadiran siswa dan menyiapkan siswa untuk belajar, kemudian menyampaikan tujuan pembelajaran, dan memberikan apersepsi mengenai materi yang akan diajarkan. Peneliti memberikan arahan dan menyampaikan tujuan pembelajaran yang akan dicapai. Hal ini sesuai dengan pendapat Kardi dan Nur [3] yang menyatakan bahwa tidak memandang model pembelajaran yang digunakan, guru yang baik mengawali pelajaran mereka dengan menjelaskan tujuan pembelajaran mereka.

Peneliti memberikan apersepsi dengan mengingatkan atau mengecek pengetahuan prasyarat siswa pada materi yaitu operasi bilangan, persamaan kuadrat dengan tanya jawab, serta guru memperbaiki serta memberikan penguatan 
terhadap pengetahuan prasyarat siswa. Hal ini sejalan dengan pendapat Ningsih [4] yang menyatakan bahwa kegiatan memberikan apersepsi adalah kegiatan yang dilakukan oleh guru untuk menciptakan suasana siap mental dan menimbulkan perhatian siswa agar terpusat pada hal-hal yang akan dipelajari.

Peneliti memberikan motivasi kepada seluruh siswa. Hal ini sesuai dengan pendapat Hudojo [5] yang menyatakan bahwa betapa pentingnya menimbulkan motivasi belajar siswa, sebab siswa yang memiliki motivasi untuk belajar akan lebih siap belajar dari pada siswa yang tidak memiliki motivasi belajar. Selanjutnya guru memberikan contoh masalah dalam kehidupan sehari-hari dengan menampilkan permasalahan matematika. Siswa juga memperlihatkan antusiasme yang tinggi untuk mempelajari materi dengan merespon balik seluruh tanggapan guru terhadap motivasi yang diberikan. Sebagaimana pendapat Herman [6] bahwa penyajian gambar dapat menumbuhkan minat dan motivasi siswa dalam memecahkan masalah yang diberikan, selain itu juga dapat membantu siswa untuk memperoleh gambaran ataupun petunjuk untuk menemukan solusi. Hal ini didukung oleh pendapat Ismaimuza [7] bahwa siswa dihadapkan pada masalah nyata atau masalah yang disimulasikan, siswa bekerjasama secara berkelompok untuk mengembangkan keterampilan memecahkan masalah (problem solving), kemudian siswa mendiskusikan apa yang harus dilakukan dan bernegoisasi untuk membahasnya.

Peneliti mempresentasikan materi kepada seluruh siswa dengan metode ceramah dan tanya jawab. Dalam mempresentasikan materi, peneliti menggunakan media papan tulis, dan buku sebagai media penyampai informasi. Hal ini didukung oleh pemikiran Arends [8] yang menyatakan bahwa guru berperan sebagai penyampai informasi dan dalam hal ini guru seyogyanya menggunakan berbagai media yang sesuai, misalnya film, tape recorder, gambar, peragaan dan sebagainya.

Hasil yang didapatkan pada kegiatan awal ini adalah respon siswa terhadap peneliti yang cukup bagus bahwa siswa memperhatikan dengan baik seluruh penyampaian guru. Hal ini terlihat pada saat guru memberikan motivasi dikehidupan sehari-hari yang berkaitan dengan materi persamaan kuadrat, seluruh perhatian siswa terfokus pada penyampaian guru. Sebagaimana pendapat Arends [9] bahwa bila perilaku digerakkan secara internal oleh minat atau keingintahuan kita sendiri atau semata-mata karena kesenangan murni yang didapat dari sebuah pengalaman menyebabkan orang bertindak dengan cara tertentu karena tindakan itu membawa kepuasan atau kesenangan pribadi.

Pelaksanaan pembelajaran siklus I dan siklus II mengikuti fase-fase model PBL yang dikemukakan oleh Fathurrohman [10] yang terdiri dari 5 tahap atau fase, yaitu (1) Orientasi siswa pada masalah; (2) Mengorganisasikan siswa untuk belajar; (3) Membantu penyelidikan individual maupun kelompok; (4) Mengembangkan dan menyajikan hasil karya; dan (5) Menganalisis dan mengevaluasi proses pemecahan masalah.

Hasil yang diperoleh pada fase 1 adalah hampir semua siswa termotivasi untuk mempelajari materi persamaan kuadrat dengan memperhatikan penyampaian peneliti dan aktif mencari tahu cara penyelesaian masalah persamaan kuadrat pada siklus I. Sebagaimana pendapat Arends [9] bahwa mengorientasikan siswa pada masalah dengan dorongan guru yang melibatkan siswa untuk menemukan pemecahan masalah. Pada siklus II dengan memberikan tanggapan terhadap masalah yang diberikan oleh peneliti melalui penjelasan dan contoh yang diberikan, siswa dapat memahami proses memecahkan masalah yang sedang dipelajari.

Memasuki kegiatan inti yang meliputi fase 2 yaitu mengorganisasikan siswa untuk belajar. Hasil yang diperoleh pada fase ini di siklus I adalah masih ada siswa yang menunjukkan ketidak setujuannya dengan kelompoknya yang telah ditentukan. Sebagaimana pendapat Arends [9] bahwa guru dapat menentukan strukturnya dalam membentuk kelompok-kelompok dan menentukan prosedur secara keseluruhan, tetapi siswa dibiarkan mengontrol interaksi dari menit ke menit di dalam kelompok. Pada fase ini di siklus II adalah semua siswa langsung membentuk kelompok heterogen sesuai dengan anggota kelompok yang telah ditentukan oleh peneliti. Hal ini dikarenakan peneliti telah menasehati siswa-siswa dengan baik, dan menekankan bahwa mereka harus bisa berkomunikasi dengan baik kepada semua teman-teman di kelasnya.

Peneliti meminta siswa membentuk kelompok belajar yang heterogen dan memberikan LKPD untuk dikerjakan, dengan pembelajaran secara berkelompok siswa akan mudah mendapatkan solusi dari Permasalahan yang diberikan. Hal ini didukung oleh pendapat Arends [9] dan Trianto[11] yang menyatakan bahwa dengan bekerja bersama dapat memberikan motivasi dan dapat mengembangkan keterampilan sosial dan keterampilan berpikir.

Hasil yang diperoleh pada fase 3 (membantu penyelidikan individu maupun kelompok) adalah siswa mampu untuk mengungkapkan ide-ide mereka dalam menjawab masalah yang ada dalam LKPD melalui diskusi kelompok. Namun, pada langkah ini di siklus I peneliti masih terlalu banyak memberikan bantuan sehingga masih perlu diperbaiki. Selain itu, siswa sudah dapat menyelesaikan soal yang berkaitan dengan materi persamaan kuadrat dalam kehidupan sehari-hari dengan bantuan seperlunya dari peneliti jika siswa mengalami kesulitan pada siklus II. Siswa saling berdiskusi dengan teman sekelompoknya membahas penyelesaian masalah pada LKPD. Hal ini sesuai dengan pendapat Vygotsky [9] bahwa belajar terjadi melalui interaksi sosial dengan guru dan teman sebaya.

Peneliti berkeliling memantau dan mengontrol jalannya diskusi kelompok. Peneliti mengamati dan memberikan bimbingan atau petunjuk terbatas pada siswa yang kesulitan berkaitan dengan langkah kerja. Hal ini sesuai dengan pendapat Safi'i dan Nusantara [12] yang menyatakan bahwa seorang guru memiliki kewajiban dalam mengatasi kesulitan yang dialami siswa pada proses belajarnya dengan melakukan upaya pemberian bantuan seminimal mungkin atau yang lebih dikenal dengan istilah scaffolding. Hal ini sejalan dengan pendapat Widjajanti [12] bahwa dalam keadaan diskusi menemui kebuntuan, guru dapat memancing 
ide siswa dengan pertanyaan yang menantang, atau memberi petunjuk kunci tanpa mematikan kreativitas.

Hasil yang diperoleh pada fase 4 (mengembangkan dan menyajikan hasil karya) di siklus I adalah siswa sudah mampu mempresentasikan hasil pekerjaan kelompoknya dengan penguasaan topik dan proses pengerjaan yang cukup baik. Hasil yang diperoleh pada fase ini di siklus II adalah siswa sudah mampu mempresentasikan hasil pekerjaan kelompoknya dengan penguasaan topik dan proses pengerjaan yang cukup baik pula. Siswa juga menunjukkan sikap bertanggung jawab di dalam kelompoknya, yaitu ketika salah seorang siswa yang bersedia maju presentasi saat diminta oleh peneliti. Hal ini sejalan dengan pendapat Sukmadinata [13] bahwa penilaian belajar, selain didasarkan pada hasil belajar juga didasarkan pada aktivitas belajar siswa.

Hasil yang diperoleh pada fase 5 (menganalisis dan mengevaluasi proses pemecahan masalah) adalah siswa sudah mampu menganalisis hasil proses pemecahan masalah persamaan kuadrat pada siklus I dan siklus II pada hasil presentasi tiap-tiap kelompok dengan kemampuan intelektual yang telah mereka peroleh selama pembelajaran. Hal ini terlihat saat siswa mampu menemukan kesalahan dan menjelaskan dengan baik jawaban yang benar saat tanya jawab. Hal ini sejalan dengan pendapat Piaget [9] bahwa pedagogi yang baik itu harus melibatkan penyodoran berbagai situasi dimana anak bisa bereksperimen, yang dalam artinya yang paling luas, yaitu memanipulasi simbolsimbol, melontarkan pertanyaan dan mencari jawabannya sendiri, dan membandingkan temuannya dengan temuan anak-anak lain.

Peneliti memberikan kesempatan kepada siswa untuk bertanya mengenai hasil presentasi yang dibawakan oleh temannya kemudian merefleksi kegiatan pembelajaran dengan cara tanya jawab. Hal ini sesuai dengan pendapat Fachrurazi [14] yang menyatakan bahwa tanya jawab dan diskusi, yaitu menguji keakuratan dari solusi dan melakukan refleksi terhadap pemecahan masalah yang dilakukan.

Dalam merefleksi pembelajaran peneliti bersama-sama melakukannya dengan siswa dengan cara umpan balik. Hal ini sesuai dengan pendapat Trianto [11] bahwa tugas guru pada tahap akhir pengajaran berdasarkan pemecahan masalah adalah membantu siswa menganalisis dan mengevaluasi proses berpikir mereka sendiri, dan keterampilan penyelidikan yang mereka gunakan.

Hasil pada kegiatan penutup adalah siswa sudah mampu dalam menyimpulkan materi persamaan kuadrat pada siklus I dan persamaan kuadrat pada siklus II. Hal ini terlihat saat hampir seluruh siswa menanggapi seluruh pertanyaan peneliti tentang materi yang telah mereka pelajari di dalam pembelajaran. Kemampuan siswa dalam membuat kesimpulan dengan baik ini karena siswa sudah dapat mengkonstruksi pengetahuan yang diperoleh pada saat bekerja dalam kelompok belajar untuk menyelesaikan masalah. Hal ini sejalan dengan pendapat [9] bahwa pengetahuan tidak statis, tapi berevolusi dan berubah secara konstan selama pelajar mengkonstruksikan pengalaman- pengalaman baru yang memaksa mereka untuk mendasarkan pada diri dan memodifikasi pengetahuan sebelumnya.

Kegiatan ini merupakan kegiatan akhir dalam proses pembelajaran. Peneliti menyampaikan informasi mengenai hal yang akan dilakukan pada pertemuan selanjutnya yaitu melaksanakan tes akhir tindakan setiap selesai pembelajaran. Hal ini bertujuan agar siswa tekun dalam belajar sebelum tes akhir tindakan dilaksanakan. Selanjutnya peneliti membimbing siswa untuk menyimpulkan secara umum hasil penemuannya dan memberikan Pekerjaan Rumah (PR) kepada siswa dengan tujuan agar siswa dapat melatih kemampuannya dalam menyelesaikan soal yang berhubungan dengan materi persamaan kuadrat, selanjutnya peneliti menutup pembelajaran dengan berdoa dan mengucapkan salam.

Berdasarkan hasil observasi pembelajaran siklus I, diperoleh hasil observasi aktivitas guru (peneliti) dalam mengolah pembelajaran dan aktivitas siswa berkategori baik. Hal itu terlihat dari total skor hasil observasi aktivitas guru yang diperoleh sebesar 56 dengan persentase $77,7 \%$ dan total skor hasil observasi aktivitas siswa sebesar 48 dengan persentase $66,6 \%$ tetapi proses pembelajaran belum mencapai hasil yang diharapkan yaitu ketuntasan belajar klasikal pada siklus I mencapai 47,2\%. Hal ini berarti pelaksanaan tindakan pada siklus I masih perlu diperbaiki pada siklus II, terutama pembiasaan menggunakan langkahlangkah model PBL dengan materi persamaan kuadrat.

Proses pembelajaran siklus II berjalan lebih baik dan mengalami peningkatan bila dibandingkan dengan proses pembelajaran sebelumnya. Hal ini tidak lepas dari hasil perbaikan terhadap kekurangan-kekurangan yang terjadi pada siklus I. Selain itu, hampir seluruh siswa aktif dalam mengikuti pembelajaran baik dalam bertanya, berdiskusi dalam kelompok maupun memaparkan hasil pekerjaannya. Hasil perbaikan terhadap kekurangan pada siklus I dan keaktifan siswa yang meningkat ternyata berdampak pada hasil belajar siswa yang semakin baik yang terlihat dari hasil pelaksanaan tes akhir tindakan pada siklus II yang mencapai ketuntasan belajar klasikal yaitu 77,7\%. Aktivitas guru dan siswa juga lebih baik jika dibandingkan dengan siklus sebelumnya. Pada siklus II, aktivitas guru total skor mencapai 67 dengan presentase sebesar 93,05\% dan aktivitas siswa total skor mencapai 66 dengan presentase sebesar $91,66 \%$.

\section{KESIMPULAN}

Berdasarkan hasil penelitian dan pembahasan dapat disimpulkan bahwa penerapan model PBL yang dapat meningkatkan hasil belajar siswa pada materi persamaan kuadrat di kelas X IPA 4 SMA Negeri 1 Torue, dengan mengikuti fase-fase sebagai berikut: 1) Fase 1 : orientasi siswa pada masalah, peneliti memunculkan masalah dalam bentuk contoh soal dan peneliti mengajak siswa untuk terlibat aktif dalam pemecahan masalah tersebut. 2) Fase 2 : mengorganisasikan siswa untuk belajar, peneliti mengorganisasikan siswa kedalam beberapa kelompok yang terdiri dari 6 siswa dan membagikan LKPD pada masingmasing kelompok. 3) Fase 3 : membantu penyelidikan 
individual maupun kelompok, yaitu peneliti meminta siswa untuk mengamati masalah yang terdapat pada LKPD bersama teman kelompok, meminta siswa untuk melakukan penyelidiikan kelompok mengenai masalah yang terdapat pada LKPD, mendiskuikan hasil penyelidikan kelompok secara bersama, dan membimbing siswa yang mengalami kesulitan. 4) Fase 4 : mengembangkan dan menyajikan hasil karya, peneliti meminta perwakilan kelompok untuk mempresentasikan hasil pekerjaan kelompoknya yang terdapat pada LKPD. 5) Fase 5: menganalisis dan mengevaluasi pemecahan masalah, peneliti memberikan kesempatan kepada siswa untuk bertanya atau mengomentari mengenai hasil presentasi yang dibawakan oleh temannya, serta peneliti meminta siswa untuk merefleksi kegiatan pembelajaran yang telah dilakukan secara bersama-sama.

\section{SARAN}

Berdasarkan kesimpulan di atas, peneliti menyarankan bahwa dalam melaksanakan pembelajaran matematika, diharapkan guru dapat menjadikan model PBL sebagai alternatif pembelajaran untuk meningkatkan hasil belajar siswa. Bagi peneliti lain yang ingin menggunakan model PBL, diharapkan mencoba menerapkan model PBL pada materi lain untuk mengetahui efektivitas pembelajaran ini untuk meningkatkan hasil belajar siswa pada pelajaran matematika dan lebih memperhatikan pengelolaan waktu ysng digunakan agar pembelajaran dapat berlangsung efektif.

\section{REFFERENSI}

[1] S. Arikunto, "Penelitian Tindakan Kelas," Jakarta: Bumi Aksara, 2007.

[2] Sutrisno. (2012 ). "Efektivitas Pembelajaran dengan Metode Penemuan Terbimbing Terhadap Pemahaman Konsep Matematis Siswa”. Dalam Jurnal Pendidikan Matematika.[Online].Tersedia:http://fkip.unila.ac.id/ojs/ data/journals/II/JPMUVol1No4/016-Sutrisno.pdf.

[3] S. Kardi, dan M. Nur, "Pengajaran Langsung," Surabaya: Universitas Negeri Surabaya, 2005.

[4] Ningsih. (2013). "Perbedaan Pengaruh Pemberian Apersepsi Terhadap Kesiapan Belajar Siswa Mata Pelajaran IPS Kelas VII A". Dalam Jurnal Untan [Online].Tersedia:http://jurnal.untan.ac.id/index.php/jpd pb/art cle/down load/2349/2281. [10 November 2018].

[5] H. Hudojo, "Strategi Mengajar Belajar Matematika," Malang: IKIP Malang, 1990.

[6] T. Herman. (2012). "Membangun Pengetahuan Siswa Melalui Pembelajaran Berbasis Masalah". Dalam Jurnal UPI.[Online].Tersedia:http://file.upi.edu/Direktori/FPMI PA/JUR._PEND._MATEMATIKA/196210111991011T ATANG_HERMAN/Artikel/mkalah2taher.pdf.
[7] D. Ismaimuza. (2010). "Pengaruh Pembelajaran Berbasis Masalah Dengan Strategi Konflik Kognitif Terhadap Kemampuan Berpikir Kritis Matematis dan Sikap Siswa SMP”. Jurnal Pendidikan Matematika [Online].Tersedia:http://ejournal.unsri.ac.id/index.php/jp m/article /view/305

[8] N. M. Miartini, "Penerapan Model Problem Based Learning untuk Meningkatkan Hasil Belajar Siswa pada Materi Pertidaksamaan Linear Satu Variabel di Kelas VII Asmpnegeri 1 Palu," Palu: Universitas Tadulako, 2017.

[9] R. I. Arends, "Learning To Teach (Belajar untuk Mengajar) Edisi Ketujuh, " Yogyakarta: Pustaka Pelajar, 2008.

[10] M. Fathurrohman, "Model-model Pembelajaran Inovatif : Alternatif Desain Pembelajaran yang Menyenangkan," Jakarta: Ar-Ruzz Media, 2015.

[11] Trianto, "Mendesain Model Pembelajaran Inovatif Progresif,” Surabaya: Prenada Media Grup, 2009.

[12] Paloloang. (2014). "Penerapan Model Problem Based Learning (PBL) Untuk Meningkatkan Hasil Belajar Siswa Pada Materi Panjang Garis Singgung Persekutuan Dua Lingkaran Di Kelas VIII SMP Negeri 19 Palu”. [Online]. Tersedia:http://jurnal.untad.ac.id/jurnal/index.php/JEPMT/a rticle/view/3232.

[13]N. S. Sukmadinata, "Landasan Psikologis Proses Pendidikan,” Bandung: Remaja Rosdakarya, 2005.

[14]Fachrurazi. (2011). "Penerapan Pembelajaran Berbasis Masalah untuk Meningkatkan Kemampuan Berpikir Kritis dan Komunikasi Matematis Siswa Sekolah Dasar". [Online]. Tersedia:http://jurnal.upi.edu/file/8Fachrurazi.pdf. 